\title{
TECHNOLOGY INTEGRATION IN NATURAL SCIENCES TEACHING AND LEARNING IN SOUTH AFRICAN TOWNSHIP SCHOOLS
}

\author{
Sam Ramaila \\ Department of Science and Technology Education, University of Johannesburg (South Africa)
}

\begin{abstract}
This study examined technology integration in Natural Sciences teaching and learning in South African township schools. A mixed method approach was adopted as part of an exploratory descriptive survey design. Data was collected through semi-structured interviews, classroom observations as well as administration of open-ended survey questionnaire. The study involved purposively selected grade 9 Natural Sciences teachers and learners as participants. The empirical investigation is underpinned by technological pedagogical content knowledge (TPACK) as the underlying theoretical framework. The participants demonstrated a positive disposition about technology integration in Natural Sciences teaching and learning. In particular, technology integration was perceived to provide opportunities for the enhancement of meaningful Natural Sciences teaching and learning in township schools. Digital resources were largely viewed as essential educational tools that can be deployed to demystify abstract scientific concepts with a view to enhance scientific literacy. Theoretical implications for technology-enhanced teaching and learning are discussed.
\end{abstract}

Keywords: Technology integration, TPACK, technology-enhanced learning, digital resources.

\section{Introduction}

The advent of the Fourth Industrial Revolution provides meaningful opportunities for embracing pedagogic innovation as an integral part of digital transformation. However, there is a crucial need to bridge the digital divide between under-resourced and well-resourced schools within the broader South African context. Challenges stifling meaningful integration of technology in teaching and learning include poor literacy of educators (Johnson, Jacovina, Russell \& Soto, 2016). Bozkurt (2014) posits that teachers do not have knowledge about technology and technological pedagogical content knowledge (TPACK) as a whole. Costley (2014) asserts that technology has become a common tool that most people use in their households and schools. Technology integration has the potential to transform teacher-centred environments into learner-centred environments. Learner-centred environments provide opportunities for learners to become more flexible and to take charge of their learning (Keser, Uzunboylu \& Ozdamli, 2012). In support of this notion, Miller (2011) posits that learners develop their technological abilities through sustained practice and involvement in teaching and learning.

\section{Background}

Meaningful information and communication technology (ICT) integration in the classroom is hampered by a myriad of factors. These factors include lack of time (Assan \& Thomas, 2012), lack of clarity regarding the e-Education Policy (Vandeyar, 2015), lack of support both in terms of infrastructure and policy (Vandeyar, 2015), lack of skills (Msila, 2015) and more focus on the technical aspects as opposed to the pedagogical and theoretical frameworks (Tamim et al., 2015). ICT integration in teaching and learning remains a key focus area across the globe. Many companies are investing in ICT infrastructure, equipment and professional development in order to improve teaching and learning in schools (Buabeng-Andoh, 2012). The current belief is that ICT is an important catalyst and tool for encouraging educational reforms that transform students into productive knowledge workers (Pelgrum, 2001). Technology is a powerful and flexible tool for learning as it has also become an important part of student lives' beyond and within the classroom (Rabah, 2015). In addition, Rabah (2015) further argues that the 
primary goal of educational technology within a pedagogical context is to facilitate the teaching and learning process. There is a critical need to examine the complexity of barriers impeding ICT integration in teaching and learning with a view to foster pedagogic innovation within the broader South African context.

\section{Research design and methodology}

This study adopted a mixed method approach as part of exploratory descriptive survey design located within the interpretivist paradigm. Exploratory descriptive survey design makes provision for the determination and description of the situation and comparing how sub-groups view a certain issue (Gay, Mills, \& Airasian, 2011). According to Burns and Bush (2006), exploratory research design provides opportunities for gathering information in an informal and unstructured manner. Exploratory research helps a researcher to build understanding about the problem of the research. In addition, exploratory research design is not limited to one specific paradigm as it may use either qualitative or quantitative approaches. Data was collected through semi-structured interviews, classroom observations as well as administration of open-ended survey questionnaire. The study involved purposively selected grade 9 Natural Sciences teachers and learners as participants.

\section{Research findings}

Table 1 below provides participants' level of proficiency associated with various competencies. While the participants demonstrated moderate levels of proficiency in relation to various competencies, they demonstrated a positive disposition about technology integration in Natural Sciences teaching and learning. In particular, technology integration was perceived to provide opportunities for the enhancement of meaningful Natural Sciences teaching and learning in township schools. Digital resources were largely viewed as essential educational tools that can be deployed to demystify abstract scientific concepts with a view to enhance scientific literacy.

Table 1. Participants' level of proficiency associated with various competencies.

Competency

Level of proficiency

Learning how to use a new application

Moderate

Acting as a guide to learners when teaching using the internet

Satisfactory

Troubleshooting problems that occur when using technology

Moderate

Using technology to differentiate technology

Moderate

Table 2 below depicts participants' opinions about technology integration in Natural Sciences teaching and learning. While the participants expressed varied opinions about technology integration in Natural Sciences teaching and learning, they expressed fundamental appreciation of the key pedagogical affordances of technology integration. Access to technological resources remained a pervasive challenge for teachers and learners in township schools. Harnessing the affordances of technology integration requires provision of adequate resources. In addition, there is a need to provide training for teachers on technology integration in order to strengthen their professional competence to fully embrace technology-enhanced teaching and learning. 
Table 2. Participants' opinions about technology integration in Natural Sciences teaching and learning.

\begin{tabular}{|c|c|c|c|c|}
\hline Statement & $\begin{array}{c}\text { Strongly } \\
\text { Agree }\end{array}$ & Agree & Disagree & $\begin{array}{l}\text { Strongly } \\
\text { Disagree }\end{array}$ \\
\hline \multicolumn{5}{|l|}{ When using the internet... } \\
\hline $\begin{array}{l}\text { Learners create products that show higher } \\
\text { levels of learning }\end{array}$ & 15 & 28 & 10 & 7 \\
\hline Learners are more motivated & 25 & 20 & 10 & 5 \\
\hline There is more student collaboration & 20 & 15 & 15 & 10 \\
\hline $\begin{array}{l}\text { The abundance of unreliable sources is } \\
\text { disturbing }\end{array}$ & 2 & 58 & 0 & 0 \\
\hline \multicolumn{5}{|l|}{ I think... } \\
\hline $\begin{array}{l}\text { Electronic media will replace printed text } \\
\text { within five years }\end{array}$ & 10 & 20 & 20 & 10 \\
\hline $\begin{array}{l}\text { Learners are more knowledgeable than I am } \\
\text { when it comes to technology }\end{array}$ & 10 & 50 & 0 & 0 \\
\hline $\begin{array}{l}\text { Technology is a good tool for } \\
\text { collaboration with other teachers when } \\
\text { building unit plans }\end{array}$ & 2 & 58 & 0 & 0 \\
\hline Technology is unreliable & 15 & 35 & 5 & 5 \\
\hline
\end{tabular}

\section{Discussion}

While the participants expressed positive disposition about technology integration in Natural Sciences teaching and learning, access to essential resources remained a pervasive challenge. The participants demonstrated moderate levels of proficiency in relation to various competencies. Teachers are often overwhelmed by heavy teaching loads which do not make provision for training opportunities (Sabaliauskas, Ghavifekr et al., 2016). According to Laabidi and Laabidi (2016), there is a critical need to enhance professional competence of teachers through skills training to ensure that learners are adequately prepared for a technological society. Teachers who have little or no confidence to apply technologies in their occupation will try to escape from those occupations altogether (Laabidi \& Laabidi, 2016). The teachers acknowledged the fact that learners were more knowledgeable than them when it comes to technology use. Technology was perceived to be a good tool for collaboration with other teachers when building unit plans. However, the teachers bemoaned the fact that technology can often be unreliable. There is a crucial need to enhance teachers' technological pedagogical content knowledge with a view to foster meaningful ICT integration in teaching and learning (Cox et al, 1999).

\section{Conclusion}

Technology integration can serve as an innovative catalyst to foster pedagogic innovation in Natural Sciences teaching and learning in township schools. There is a crucial need to enhance teacher professional competence on technology integration with a view to enable them to fully embrace digital transformation.

\section{References}

Bozkurt, E. (2014). TPACK levels of physics and science teacher candidates: Problems and possible solutions. Asia-Pacific Forum on Science Learning and Teaching, 15(2), Article 5, p.1

Buabeng-Andoh, C. (2012). Factors Influencing Teachers' Adoption and Integration of Information and Communication Technology into Teaching: A Review of the Literature. International Journal of Education and Development using Information and Communication Technology (IJEDICT), 8, 136-155.

Burns, A.C. \& Bush, R.F. (2006). Marketing Research ( $5^{\text {th }}$ edition). New Jersey: Prentice Hall.

Costley. K. C., (2014). The positive effects of technology on teaching and student learning. Arkansas Tech University.

Cox, M., Preston, C., Cox, C. (1999). What factors support or prevent teachers from using ICT in the primary classroom. Paper presented at the British Educational Research Association Annual Conference. University of Sussex at Brighton. (September 2-5 1999). 
Gay, Mills, \& Airasian (2011). Educational research: Competencies for analysis and applications (10th edition).

Johnson, A. M., Jacovina, M. E., Russell, D. G., \& Soto, C. M. (2016). Challenges and solutions when using technologies in the classroom. In Adaptive educational technologies for literacy instruction (pp. 13-30). Routledge.

Keser, H., Uzunboylu, H., and Ozdamli, F. (2012). The trends in technology supported collaborative learning studies in 21 st century. World journal on educational technology, 3(2), 103-119.

Laabidi, Y., \& Laabidi, H. (2016). Barriers Affecting Successful Integration of ICT in Moroccan Universities. Journal of English Language Teaching and Linguistics, 1(3). doi: 10.21462/jeltl.v1i3.29

Miller, S. (2011). Student voice for change. Learning and leading with technology, 38(8), 20-23.

Msila, V. (2015). Teacher readiness and Information and Communications Technology (ICT) use in classrooms: A South African case study. Creative Education, 6(18), 1973-1981.

Pelgrum, W. (2001). Obstacles to the integration of ICT in education: results from a worldwide educational assessment. Computers \& Education, 37(2), 163-178.

Rabah, J. (2015). Benefits and challenges of Information and Communication Technologies (ICT) Integration in Quebec English Schools. The Turkey online Journal of Educational Technology, 14(2), 24-31.

Sabaliauskas, T., \& Pukelis, K. (2004). Barriers to integration of information and communication technologies into the teaching and learning process. Presentation, European Conference on Educational Research, University of Crete., 22-25, September 2004.

Tamim, R., Borokhovski, E., Pickup, D., Bernard, R. (2015). Large-scale, government-supported educational tablet initiatives. Burnaby, BC: Commonwealth of Learning.

Vandeyar, T. (2015). Policy intermediaries and the reform of e-Education in South Africa. British Journal of Educational Technology, 46, 344-359. 